Article

\title{
Bees Occurring in Corn Production Fields Treated with Atoxigenic Aspergillus flavus (Texas, USA)
}

\author{
Krishna B. Bhandari *D, Scott D. Longing and Charles P. West $\mathbb{D}$ \\ Department of Plant and Soil Science, Texas Tech University, Lubbock, TX 79409, USA; \\ scott.longing@ttu.edu (S.D.L.); chuck.west@ttu.edu (C.P.W.) \\ * Correspondence: krishna.bhandari@ttu.edu
}

Received: 11 March 2020; Accepted: 13 April 2020; Published: 16 April 2020

check for updates

\begin{abstract}
A saprophytic soil fungus, Aspergillus flavus, produces aflatoxin (toxigenic strains) in the kernels of corn (Zea mays L.) and seeds of many other crops. Many strains of A. flavus do not produce toxigenic aflatoxin, and soil application of these atoxigenic strains is a suppressive control tactic to assist in controlling toxigenic conspecifics. Effects of atoxigenic A. flavus applications on honey bees (Apis mellifera L.) and other bees are unknown, and basic information on bee occurrences in cornfields treated with and without this biological agent is needed to inform integrated pest management in corn. Fields receiving atoxigenic $A$. flavus applications of FourSure ${ }^{\mathrm{TM}}$ were compared to nearby control fields in three counties in corn production regions in eastern Texas. In each cornfield, 20 bee bowl traps were deployed along four equal transects located between corn rows, with contents of the bowls (i.e., bees) retrieved after $24 \mathrm{~h}$. Eleven bee genera from four families were collected from cornfields, with only two honey bees collected and zero honey bees observed in transects. The sweat bee genus Agapostemon (primarily composed of the Texas striped sweat bee A. texanus) was most abundant in cornfields ( $44 \%$ of the total number of bees collected), followed by long-horned bees (Melissodes spp., 24\%). The southernmost county (i.e., San Patricio) produced over $80 \%$ of the total number of bees collected. Bee numbers occurring in cornfields with applications of atoxigenic A. flavus applications were not significantly different from those of nearby control fields. Although not statistically significant, total numbers of bees tended to be lower in FourSure-treated fields than in control fields. More extensive research on bee abundances in relation to the effect of atoxigenic A. flavus is warranted.
\end{abstract}

Keywords: aflatoxin treated corn; Aspergillus flavus; atoxigenic aflatoxin; bee community; biological agent; saprophytic soil fungus

\section{Introduction}

Aspergillus flavus is a common saprophytic soil fungus that produces toxigenic aflatoxin in the kernels of corn (Zea mays L.) [1], seeds of cotton (Gossypium hirsutum L.) [2], and seeds of many other crops both before and after harvest [3]. Toxigenic A. flavus causes ear rot in corn, one of the most important diseases, which diminishes grain quality and marketability, and livestock health if the affected grain is consumed. Corn yields and profitability can be negatively impacted by toxigenic $A$. flavus by producing aflatoxin before harvest and in storage [4,5], and, therefore, advancing practices for its control is necessary. A previous study reported that one of several species of Aspergillus causes stonebrood in honey bees (Apis mellifera L.) [6], and, therefore, applications of $A$. flavus should consider impacts on pollinator health.

It is expected that bees are minimally exposed to aflatoxin in cornfields, but evidence suggests bees visit corn during flowering [7] and, therefore, could be exposed to agrochemicals. The use of atoxigenic conspecific strains of $A$. flavus is the most common biocontrol method for reducing aflatoxin 
contamination in corn [8], in which toxigenic A. flavus strains were found to be displaced by atoxigenic A. flavus strains $[9,10]$. Some registered biocontrol agents that reduce toxigenic $A$. flavus populations are Aflaguard $^{\mathrm{TM}}$ (Strain NRL 21882, Syngenta, Greensboro, NC, USA) and Ensure ${ }^{\mathrm{TM}}$ (Strain AF36; Arizona Cotton Research and Protection Council, Phoenix, AZ, USA). In Texas, a new product (FourSure ${ }^{\mathrm{TM}}$ ) contains four atoxigenic strains of $A$. flavus that are expected to provide control of toxigenic A. flavus for several years following application [11]. It is recommended that FourSure ${ }^{\mathrm{TM}}$ be applied between the seventh leaf stage and tasseling [7]. Besides honey bees, another bee resource that could be exposed to and affected by applications of $A$. flavus is soil-nesting habitat for native bees, since approximately $75 \%$ of over 4000 species of wild bees in North America provision pollen in subsurface-soil brood chambers. However, how adults and immature stages of bees are affected by these applications of atoxigenic $A$. flavus strains remains largely unknown.

The impetus for this project is a need to determine if negative impacts on honey bees could occur in fields with applications of commercial atoxigenic A. flavus. In 2003, it was determined that atoxigenic $A$. flavus strain AF36 in cotton represented a low risk to honey bees, yet a high-mortality event observed in a cotton field on the thirteenth day following application [9] emphasized a need for further investigating potential non-target effects. The objectives of this study are to sample bee communities occurring across corn production fields in Texas (USA) and to compare generic richness and relative abundances of bees in fields with and without applications of atoxigenic $A$. flavus (hereafter FourSure $^{\mathrm{TM}}$ ). The conservation of wild, native bees in corn production systems and further research needs are discussed in relation to findings.

\section{Materials and Methods}

\subsection{Description of Field Sites}

The study was conducted in cornfields in three counties across a latitudinal range from north to south Texas (Figure 1). The geographical extent of the study ranged from the Blackland Prairie and Cross Timbers ecoregions in the northern part to the Coastal Prairies in the extreme southern region of the state (Figure 1). Bee community sampling was performed in FourSure-treated and nearby control cornfields in San Patricio County $\left(28^{\circ} 07^{\prime} \mathrm{N}, 97^{\circ} 49^{\prime} \mathrm{W}\right)$ near Sinton, TX, Ellis County $\left(32^{\circ} 36^{\prime} \mathrm{N}\right.$, $\left.96^{\circ} 58^{\prime} \mathrm{W}\right)$ near Waxahachie, TX, and Grayson County $\left(33^{\circ} 33^{\prime} \mathrm{N}, 96^{\circ} 30^{\prime} \mathrm{W}\right)$ near Sherman, TX, during May and June of 2019. Three treated and three nearby control fields were selected in San Patricio and Grayson counties, and five pairs of treatment-control were visited in Ellis county, TX, for a total of 11 treated and 11 control fields.

In San Patricio, corn was planted on 14 and 21 February, and FourSure was applied on 22 April of 2019 (Table 1). In Ellis County, corn was planted on 8 March and 1 April 2019, and an application of FourSure was performed on 19 May of 2019. Corn planting and the FourSure application were performed on 22 March and 6 June 2019, respectively, in Grayson County. FourSure was applied at $11.3 \mathrm{~kg} \mathrm{ha}^{-1}$ using an all-terrain vehicle-mounted spreader. Temperature and rainfall during the sampling for bees in each county are listed in Table 2. The temperature in San Patricio county was higher than in Ellis and Grayson counties during sampling. There was no rainfall in the week before sampling in San Patricio County, and thus soil surfaces of cornfields were dry during the sampling. In contrast, three rain events of $0.3,33.4$, and $0.3 \mathrm{~mm}$ occurred on $5 \mathrm{June}, 6 \mathrm{June}$, and $9 \mathrm{June}$, respectively, before the sampling date (June 11) in Ellis County. The gravimetric water content of the soil at $0-10 \mathrm{~cm}$ depth was determined by drying soil cores at $105^{\circ} \mathrm{C}$ for $48 \mathrm{~h}$ [12]. The soil surfaces in Ellis County during sampling were moist. In Grayson County, rain events of 14.5, 16, and $4.3 \mathrm{~mm}$ occurred on 16 June, 17 June, and 19 June, respectively, before the sampling date (20 June). Thus, the soil surfaces were wet during the sampling in Grayson County. During sampling in San Patricio county, there were storms moving through and occasional overcast skies and high wind speeds. The average wind speed for $24 \mathrm{~h}$ periods in San Patricio County was $5.1 \mathrm{~m} \mathrm{~s}^{-1}$, while it was 4.3 and 9.3 in Ellis and 
Grayson Counties, respectively. The stages of the corn at sampling were silking (R1) and blister (R2). Other studies in corn have shown bee abundance and diversity to be greatest during flowering $[7,13]$.

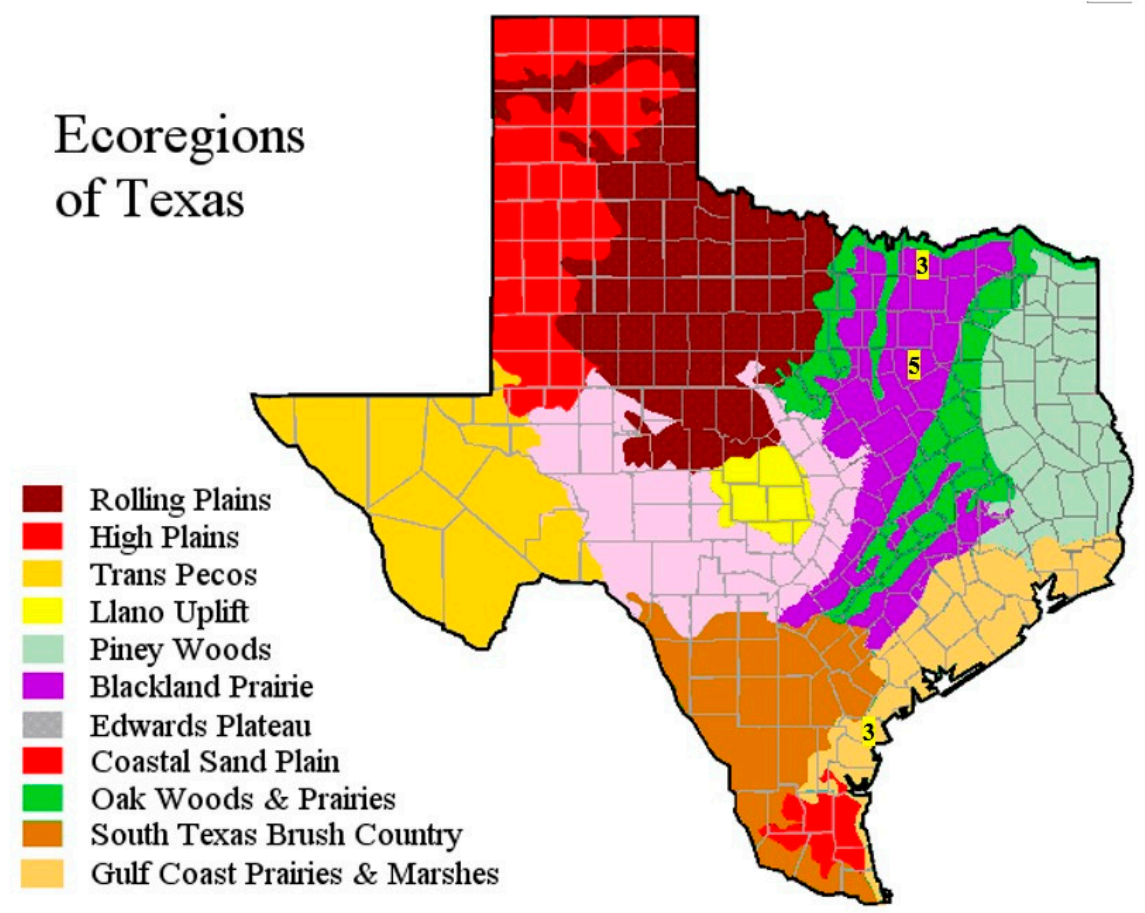

Figure 1. Ecoregions of Texas showing the counties sampled to collect bees in 2019. Number within a county is the number of pairs of control and treated fields sampled. Source: http://kidsontheland.org/ wpadmin/about-us/location/.

Table 1. Dates of corn planting, FourSure application, and bee bowl setting in sampling sites in each county in 2019.

\begin{tabular}{ccccc}
\hline \multirow{2}{*}{ Variable } & Treatment & \multicolumn{3}{c}{ County } \\
\cline { 3 - 5 } & & San Patricio & Ellis & Grayson \\
\hline Dates of corn planting & FourSure & 14 and 21 February & 8 March and 1 April & 22 March \\
& Control & 14 and 21 February & 8 March and 1 April & 22 March \\
Dates of FourSure application & FourSure & 15 and 22 April & 19 May & 6 June \\
& Control & - & - & - \\
Dates of bee bowl & FourSure & 21 May & 11 June & 20 June \\
& Control & 21 May & 11 June & 20 June \\
\hline
\end{tabular}

Table 2. Temperatures and rainfall data in each sampling site in 2019.

\begin{tabular}{|c|c|c|c|c|}
\hline \multirow{2}{*}{ Variable } & & \multicolumn{3}{|c|}{ County } \\
\hline & & San Patricio & Ellis & Grayson \\
\hline \multicolumn{5}{|l|}{ Air temperature $\left({ }^{\circ} \mathrm{C}\right)^{\dagger}$} \\
\hline \multirow{3}{*}{ Previous week of sampling } & Maximum & 31.3 & 29.8 & 30.9 \\
\hline & Minimum & 23.8 & 20.5 & 20.7 \\
\hline & Average & 27.6 & 25.2 & 25.8 \\
\hline \multirow[t]{3}{*}{ Sampling date } & Maximum & 34.4 & 26.1 & 31.4 \\
\hline & Minimum & 26.7 & 16.1 & 21.1 \\
\hline & Average & 30.6 & 21.1 & 26.3 \\
\hline Rainfall $(\mathrm{mm})^{+}$ & Total & - & 34 & 35 \\
\hline
\end{tabular}

${ }^{\dagger}$ Temperatures are in the previous week of the sampling date and on the sampling dates within each county. Rainfall is the total rainfall in the previous week of the sampling date. 


\subsection{Bee Bowl Procedure}

Pan traps (i.e., bee bowls) [14] were used to collect foraging bees. Bee bowls were set on 21 May in San Patricio County, 11 June in Ellis County, and 20 June in Grayson County (Table 1). Bee bowls were $104 \mathrm{~mL}$ plastic cups (New Horizons, Upper Marlboro, MD, USA) painted fluorescent yellow, blue, or white on the inner surface. Five bee bowls, each positioned on $0.9 \mathrm{~m}$ elevated wooded stakes, were set in each transect of $20 \mathrm{~m}$ with $5 \mathrm{~m}$ distance between adjacent bowls (Figure 2). Each field replicate contained four transects with a total of 20 bee bowls established per field. The height of bee bowls was approximately $40 \%$ of the height of silking (R1) to blister (R2) stage corn. The extent of the total area in each field sampled in the four transects was less than one ha, and field sizes ranged from 24.3 to 72.8 ha. Two-thirds of each bee bowl was filled with a water and dish soap solution (approx. 5 to 10 drops of Dawn brand liquid soap per liter of water) to serve as a capturing and killing fluid. Bee bowls were left in the field for $24 \mathrm{~h}$ after which all bees from all bowls in each field replicate were collected and transferred into labeled glass vials containing $75 \%$ ethanol for preservation. Individual bees were identified to family and genus, and relative abundances of families and genera were compared between control and FourSure-treated fields.

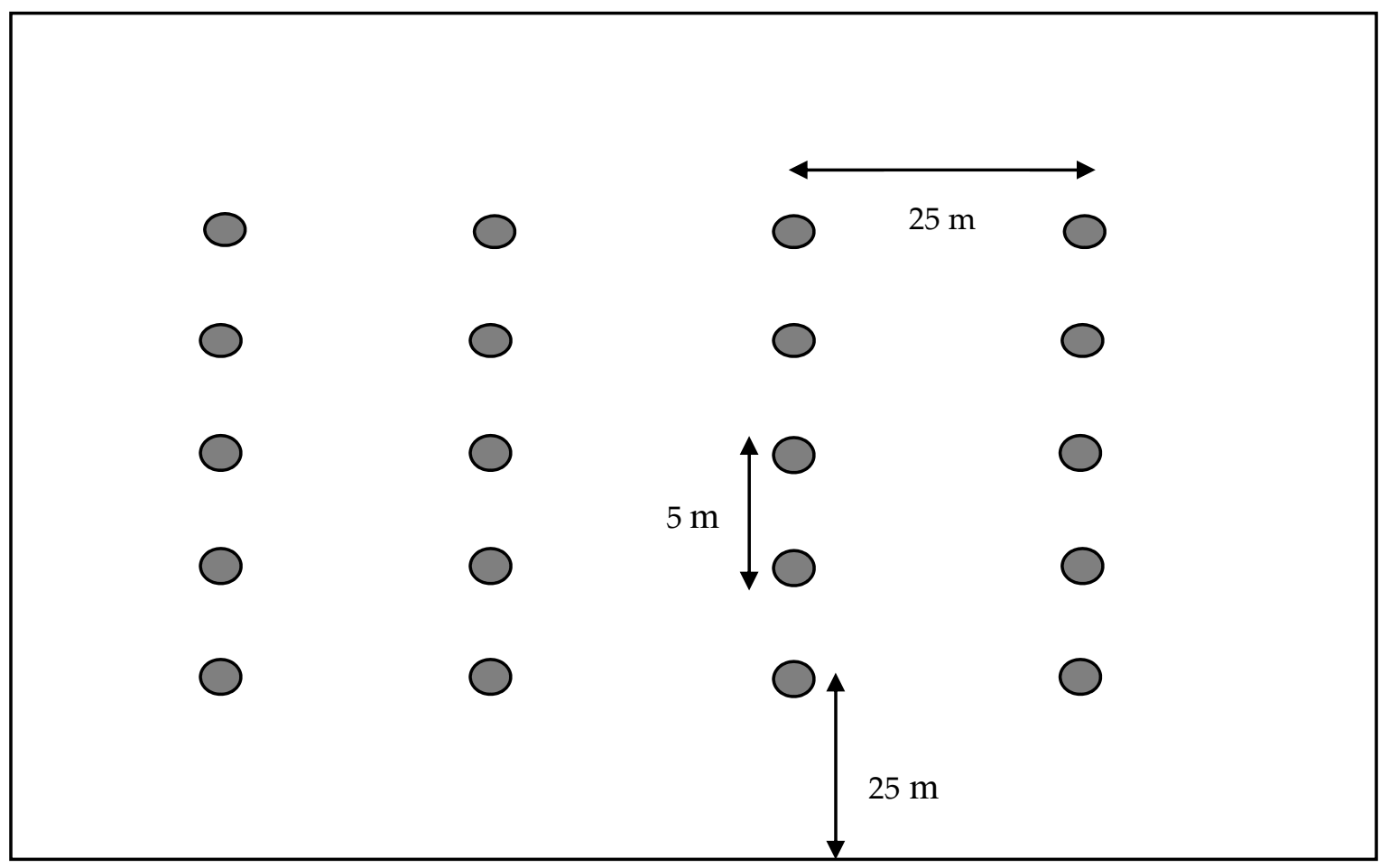

Figure 2. Diagram depicting the location within a cornfield where bees were sampled; circles represent the location of bee bowls on wooden stakes.

\subsection{Statistical Analyses}

Data were analyzed by analysis of variance consisting of two treatments (i.e., control and FourSure-applied) and three replications (five replications in Ellis County) for within-county tests. Counties were also combined to test for main effects of treatment and treatment $\times$ county interactions on bee relative abundances using Proc Mixed in SAS 9.4 [15]. A split-plot design was used for the combined analysis using 2,10 df in the F-test, in which treatments were nested within counties. A ln $(x+1)$ transformation was used for the total number of bees to normalize the data distribution. Treatments were set as fixed effects, and replicates and counties were set as random effects. Differences were considered significant at $p \leq 0.05$. An analysis of three dominant bee taxa was conducted only from San Patricio County because of sufficient data. 


\section{Results}

Eleven bee genera among four families were collected: Apidae, Colletidae, Halictidae, and Megachilidae, with a total collection of 248 bees (Table 3). The Texas striped sweat bee (Agapostemon texanus Cresson) accounted for $44 \%$ of the total number of bees collected from three counties over the entire study period. Long-horned bee (Melissodes sp.) was the second most abundant bee in pan traps, accounting for $24 \%$ of the total number of bees collected, while the metallic sweat bee (Lasioglossum sp.), was the third-ranked bee in abundance (23\%). These three bee taxa constituted $91 \%$ of the total number of bees collected. The small carpenter bee (Ceratina sp.), chimney bee (Diadasia sp.), and sweat bees in the genus Halictus were less common (Table 3). Only two honey bee and two green sweat bee (Augochlorella sp.) individuals were collected in bee bowls, while the long-horned bee (Svastra sp.), a masked bee (Hylaeus sp.), and a leafcutter bee (Megachile sp.) were collected as singletons.

Table 3. List of families of bees and total abundances recovered by bee bowl method summed over four transects per field replicate, three replicates (five in Ellis county), and two treatments in three counties (San Patricio, Ellis, and Grayson).

\begin{tabular}{cccc}
\hline Family & Genus & Common Name & Abundance Count \\
\hline Apidae & Melissodes & long-horned bee & 59 \\
& Ceratina & small carpenter bee & 3 \\
& Diadasia & sunflower/chimney bee & 3 \\
& Apis & honey bee & 2 \\
Colletidae & Svastra & long-horned bee & 1 \\
Halictidae & Hylaeus & masked bee & 1 \\
& Agaptemon & Texas striped sweat bee & 110 \\
& Halictus & metallic sweat bee & 57 \\
& Augochlorella & sweat bee & 9 \\
Megachilidae & Megachile & leafcutter bee & 2 \\
& & & 1 \\
\hline
\end{tabular}

The numbers of bees did not differ significantly $(p=0.09-0.30)$ between FourSure-treated and control fields within any one county (Table 4). Bee numbers tended to be inferior in treated fields compared with controls in all counties. In the combined-county analysis, the main effect of treatment $(p=0.07)$ was near the critical 0.05 alpha level for significance, whereas the treatment $\times$ county interaction was not significant $(p=0.53)$. There was a greater number of bees collected in San Patricio County than in Ellis and Grayson counties.

Table 4. Number of bees summed over transects within fields compared between FourSure-treated fields and controls. Data are means across field replicates within counties and means across counties.

\begin{tabular}{cccccc}
\hline \multirow{2}{*}{ Bees } & Treatment & \multicolumn{3}{c}{ County } & \multirow{2}{*}{ Mean } \\
\cline { 3 - 4 } & & San Patricio & Ellis & Grayson & \\
\hline \multirow{2}{*}{ Total } & FourSure & 29.3 & 2.4 & 1.6 & 11.1 \\
& Control & 36.7 & 4.8 & 3.0 & 14.8 \\
& Treatment effect & $p=0.30$ & $p=0.09$ & $p=0.27$ & $p=0.07^{\dagger}$ \\
& $n$ & 3 & 5 & 3 & \\
& Treatment $x$ County & \multicolumn{4}{c}{$p=0.53^{\dagger}$} \\
\hline
\end{tabular}

Because of low numbers of bees collected in Ellis and Grayson counties, further analysis of data from San Patricio County was conducted using the three dominant taxa, i.e., Texas striped sweat bee (Agapostemon texanus), long-horned bee (Svastra sp.), and metallic sweat bee (Lasioglossum sp.) (Table 5). In San Patricio County, the differences in numbers of Texas striped sweat bees and long-horned bees 
between FourSure-treated and control fields were not significant ( $p=0.80$ and 0.63 , respectively). Although the control fields had greater numbers of metallic sweat bees than did the treated fields, the difference was not significant $(p=0.30)$.

Table 5. The number of three dominant bee genera (average over three replicated fields) across control and FourSure-treated fields in San Patricio County.

\begin{tabular}{cccc}
\hline Treatment & Agapostemon texanus & Melissodes spp. & Lasioglossum spp. \\
\hline \multicolumn{3}{c}{ (Number Per Field) } \\
\hline FourSure & 16.0 & 7.3 & 4.7 \\
Control & 16.7 & 8.0 & 9.0 \\
Treatment effect & $p=0.80$ & $p=0.63$ & $p=0.30$ \\
\hline
\end{tabular}

\section{Discussion}

This study documents honey bee and native bee communities occurring in both atoxigenic Aspergillus flavus-treated and nearby control corn fields across different corn production zones in Texas. While previous studies have reported honey bees foraging in corn [16,17], we found extremely few honey bees, which is similar to an earlier study [12] in which bee bowls were elevated at tassel height and few honey bees were recovered from traps. It was reported that the height of bee bowl placement within the corn canopy may affect the sampling accuracy of the pollinator community [18]. A previous study found a more abundant pollinator community in bee bowls deployed at tassel height than those deployed at ear height or ground height [13]. In a recent study in Texas pasturelands, honey bees were found to be the second most abundant after sweat bees of Halictidae family, using bee bowls on the soil surface [19]. Thus, it appears that the presence of extremely few honey bees in this study may not be due to bias associated with the height of the collection device (i.e., bee bowl). The dominance of Halictidae in our samples was expected considering the inherent sampling bias regarding this taxon and its typically high occurrence in pan traps/bee bowls [16,18].

Relatively high and unexpected abundances of wild native bees foraging in corn were counted in both FourSure-treated and nearby control fields in the current study. There were no differences in bee relative abundances between A. flavus-treated and control fields in each county, but greater bee abundances, particularly ground-nesting bees, were found in San Patricio County, and fields in this county generally contained lower soil moisture than those in the other sampled counties. Most native bees in Texas are ground-nesters and prefer well-drained ground habitats [20], and therefore soil conditions in corn could affect local uses by bees. Ground-nesting bees were more abundant in perennial grass pastures with low soil moisture compared to grass pastures with high soil moisture in the Texas High Plains [19]. The most abundant bee in our study was the Texas striped sweat bee followed by the long-horned bee (Table 3). Metallic sweat bee (Lassioglossum sp.) was the third most abundant bee taxon recovered in our study. These results agree with a previous study [13] in which the most abundant bee species captured was Lasioglossum sp., followed by Melissodes sp., in cornfields in Iowa.

The reasons for differences in abundances of wild bees between San Patricio and Ellis/Grayson are not known, but differences in weather conditions around the time of sampling (particularly, rainfall) may be associated with patterns observed. There was no rainfall in San Patricio County, whereas three rain events occurred in Ellis and Grayson counties prior to sampling. Measurements of soil water contents ( $\mathrm{g} \mathrm{g}^{-1}$ soil) indicated that soil water content in San Patricio County (0.15) was lower compared to Ellis (0.25) and Grayson (0.24) counties.

While landscape context was not investigated here, larger areas of wild and uncultivated habitat in farmland could be influencing bee diversity and abundances [21], and this could have influenced the variability in bee abundances observed across latitudes. Although a functional relationship between bee abundance and corn plants is not clear, the observed diversity and abundances of bees suggest that the cornfields could be providing resources for native bees. Further study of bees in corn production 
systems in Texas are needed to better understand potential negative effects of FourSure on bees in cornfields in the context of a tendency for an overall decline in bee numbers in FourSure-treated cornfields in the current study. More extensive multi-year and multi-location testing is needed to adequately ascertain the potential for declines in bee populations.

\section{Conclusions}

This study appears to be the first attempt to document bees occurring in cornfields in Texas. This survey of bees in corn was, in part, prompted by previous observations of dead honey bees in a cotton field following the application of atoxigenic A. flavus (AF36 strain) to flowering-stage cotton in Arizona. We documented the types of honey bees and wild native bees in cornfields treated with atoxigenic A. flavus. The clearest result was that both FourSure-treated and control cornfields (particularly in San Patricio County) had fairly high and unexpected abundances of wild native bees in corn. This suggests that atoxigenic FourSure had no strongly negative effects on bee communities, yet toxicological studies and more field data are needed to elucidate potential negative impacts on bees as a result of its application. Among cornfields, only two honey bees were collected or observed during this study, which suggests a dearth of honey bees in corn fields at the early reproductive stage. The reason for the greater abundance of bees in southerly San Patricio County is unknown, but differences in rainfall influencing soil moisture conditions during the sampling may have contributed to the observed variation. The potential benefits to pollinators in acquiring resources in corn (i.e., pollen and soils for nesting) and the relatively abundant wild bees found in this study suggest a need to better understand non-target impacts to native fauna in corn production systems.

Author Contributions: Conceptualization, K.B.B., S.D.L., and C.P.W.; methodology, K.B.B. and S.D.L.; investigation, K.B.B. and S.D.L.; formal analysis, K.B.B.; writing-original draft preparation, K.B.B.; writing-review and editing, S.D.L. and C.P.W.; project administration, K.B.B.; funding acquisition, K.B.B. All authors have read and agreed to the published version of the manuscript.

Funding: This research was funded by Texas Corn Producers Board (TCPB) under the 2019 Aflatoxin Research Program; https://texascorn.org.

Acknowledgments: We would like to thank cooperating growers Charles Ring and Jim Sugarek in San Patricio County, Kenneth Houdek and Scott Averhoff in Ellis County, and Bruce Wetzel and Mike Fallon in Grayson County for allowing us to sample on their cornfields and for their field assistance. Field assistance by Shirish Acharya, Surendra Yadav, and Rahul Ukey is gratefully acknowledged. We also thank Aqeela Sehrish for her laboratory assistance.

Conflicts of Interest: The authors declare no conflict of interest.

\section{References}

1. Mehl, H.L.; Cotty, P.J. Variation in competitive ability among isolates of Aspergillus flavus from different vegetative compatibility groups during maize infection. Phytopathology 2010, 100, 150-159. [CrossRef] [PubMed]

2. Cotty, P.J. Influence of field application of an atoxigenic strain of Aspergillus flavus on the populations of A. flavus infecting cotton bolls and on the aflatoxin content of cottonseed. Phytopathology 1994, 84, 1270-1277. [CrossRef]

3. Klich, M.A. Aspergillus flavus: The major producer of aflatoxin. Mol Plant Pathol. 2007, 8, 713-722. [CrossRef] [PubMed]

4. Bacon, C.W.; Nelson, P.E. Fumonisin production in corn by toxigenic strains of Fusarium moniliforme and Fusarium proliferatum. J. Food Prot. 1994, 57, 514-521. [CrossRef] [PubMed]

5. Payne, G.A. Aflatoxin in maize. Crit. Rev. Plant Sci. 1992, 10, 423-440. [CrossRef]

6. Nishie, K.; Cole, R.J.; Domer, J.W. Toxicity and neurophamacology of cyclopiazonic acid. Food Chem. Toxicol. 1985, 9, 831-839. [CrossRef]

7. US EPA. Ecological Risk Assessment for Experimental Testing of the Microbial Pesticide End-Use Product, FourSure. M (A.I.: Aspergillus Flavus Strains TCI 6F, TC35C, TC38B and) to Control Aflatoxin-Producing Toxigenic Aspergillus Flavus; EPA File Symbol 91I63-EUP-R, Tolerance Petition \#5E8397; Decision No. 508471; Submission No. 972674; DP Barcode No: 4 I 9535; E-Sub \#: 8226; US EPA: Washington, DC, USA, 2016. 
8. Jensen, A.B.; Aronstein, K.; Flores, J.M.; Vojvodic, S.; Palacio, M.A.; Spivak, M. Standard methods for fungal brood disease research. J. Apic. Res. 2013, 52, 1-39. [CrossRef] [PubMed]

9. US EPA. Environmental Hazard Assessment for the Microbial Pesticide, Aspergillus Flavus AF36 for Conditional Registration in Arizona and EUP Extension in Texas; EPA Reg. No. 071693-R.; Barcode Nos. D288777; D288782; D286708; US EPA: Washington, DC, USA, 2003.

10. Bayman, P.; Cotty, P.J. Vegetative compatibility and genetic variation in the Aspergillus flavus population of a single field. Can. J. Bot. 1991, 69, 1707-1711. [CrossRef]

11. Ehrlich, K.C. Non-aflatoxigenic Aspergillus flavus to prevent aflatoxin contamination in crops: Advantages and limitations. Front. Microbiol. 2014, 5, 50. [CrossRef] [PubMed]

12. Bhandari, K.B.; West, C.P.; Acosta-Martinez, V.; Cotton, J.; Cano, A. Soil health indicators as affected by diverse forage species and mixtures in semi-arid pastures. Appl. Soil Ecol. 2018, 132, 179-186. [CrossRef]

13. Wheelock, M.J.; O'Neal, M.E. Insect pollinators in Iowa cornfields: Community identification and trapping method analysis. PLoS ONE 2016, 11, e0143479. [CrossRef] [PubMed]

14. Droege, S.; Engler, J.D.; Sellers, E.; O'Brien, L.E. National Protocol Framework for the Inventory and Monitoring of Bees. U.S. Fish and Wildlife Service, U.S. Department of the Interior, 2016. Available online: https://ecos.fws.gov/ServCat/DownloadFile/151922 (accessed on 4 March 2020).

15. Littell, R.C.; Milliken, G.A.; Stroup, W.W.; Wilfinger, R.D.; Schabenberger, O. SAS for Mixed Models, 2nd ed.; SAS Institute: Cary, NC, USA, 2006.

16. Krupke, C.H.; Hunt, G.J.; Eitzer, B.D.; Andino, G.; Given, K. Multiple routes of pesticide exposure for honey bees living near agricultural fields. PLoS ONE 2012, 7, e29268. [CrossRef] [PubMed]

17. Keller, R.; Fluri, P.; Imdorf, A. Pollen nutrition and colony development in honey bees: Part: 1 . Bee World 2005, 86, 3-10. [CrossRef]

18. Tuell, J.K.; Isaacs, R. Elevated pan traps to monitor bees in flowering crop canopies. Entomol. Exp. Appl. 2009, 131, 93-98. [CrossRef]

19. Bhandari, K.B.; West, C.P.; Longing, S.D.; Brown, C.P.; Green, P.E.; Barkowsky, E. Pollinator abundance in semi-arid pastures as affected by forage species. Crops Sci. 2018, 58, 2665-2671. [CrossRef]

20. Warriner, M.; Hutchins, B. Management Recommendations for Native Insect Pollinators in Texas. Texas Parks and Wildlife Department, 2016. Available online: https://tpwd.texas.gov/publications/pwdpubs/media/pwd_ bk_w7000_1813.pdf (accessed on 4 March 2020).

21. Evans, E.; Smart, M.; Cariveau, D.; Spivak, M. Wild, native bees and managed honey bees benefit from similar agricultural land uses. Agric. Ecosyst. Environ. 2018, 268, 162-170. [CrossRef] 